\title{
The Impact of Medical Therapeutic Communication Effectiveness on the Quality of the Medical Service Process in Hospitals at Medan City, Indonesia
}

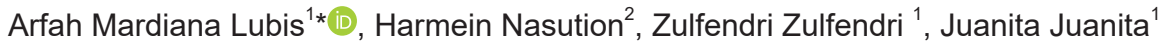 \\ ${ }^{1}$ Fakultas Kesehatan Masyarakat, Universitas Sumatera Utara, Medan, North Sumatra Province, Indonesia; ${ }^{2}$ Department of \\ Industrial Engineering and Management, Fakultas Teknik, Universitas Sumatera Utara, Medan, North Sumatra Province, Indonesia
}

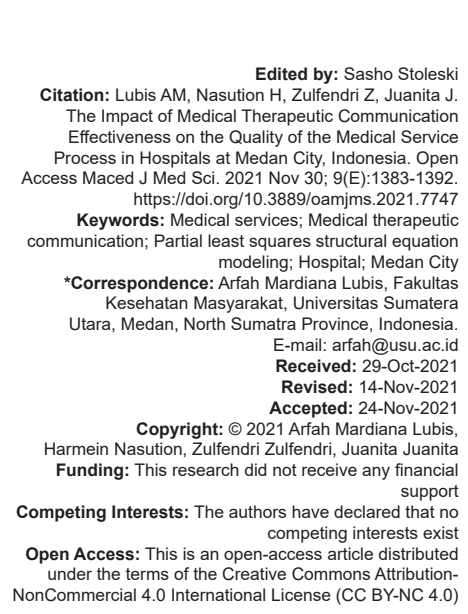

\section{Introduction}

Good health care is a human right, and health services are perceived to be of high quality when patients are satisfied with the services [1], [2], [3]. However, many individuals from Medan City, Indonesia, seek treatment abroad. Several studies have revealed that individuals seeking treatments overseas have had unsatisfactory experiences in health services provided by the city's medical staff, especially for internal, cardiac, and obstetrics and gynecology (Ob-Gyn) diseases [4], [5], [6], [7]. This is an indicator of the low quality of health services in Medan City [8], [9], [10], [11], [12], [13].

According to a study by Jannah [14]., The primary factor influencing the quality of service is the health service process itself (critical ratio: 2.417), followed by input elements (resources and facilities; critical ratio: 2.002) and environmental elements (hospital policy; critical ratio: 2.009). Medical services begin by examination (Y) of the patient by the medical staff. Patient examination service comprises the following steps: welcoming (Y1), invitation to talk (Y2), listening (Y3), explaining (Y4), discussing the stages of examination and treatment (Y5), and ending by evaluating the medical service process (Y6) [15], [16], [17], [18], [19].

Effective medical therapeutic communication skills are needed when providing medical services. In medical services, Sari [20] found that medical therapeutic communication affects patient satisfaction by $72.5 \%$. Medical therapeutic communication is said to be effective $(X)$ when it has a direct impact on the patient according to the purpose of communication. The purposes of communication in the medical service are as follows: the patient feels accepted (X1), feels comfortable expressing complaints (X2), feels the complaints are heard (X3), understands the disease, stages of 
examination, and treatment ( $\mathrm{X} 4)$, believes the treatment will be successful (X5), and agrees to undergo the treatment (X6) [15], [16], [17], [18], [21], [22].

Several studies point out that the communication by medical staff in Medan City was offtarget. Unfriendly, rude, and favoritism behaviors cause patients to feel less welcome. Medical staff that is frivolous and lacks attention and time can make patients uncomfortable in expressing complaints and feel as being overlooked. Medical staff that does not explain the condition and treatment procedures in detail results in patients having limited knowledge of the disease, stages of examination, and treatment. Thus, patients will be less confident about the suggested treatment and may choose to decline [4], [5], [6].

Based on the abovementioned aspects, we predicted that ineffective medical therapeutic communication lowers the quality of medical services in Medan City. Until this research was conducted, there was no questionnaire to assess medical therapeutic communication based on the patient's perspective, especially regarding the medical staff that works in Medan City hospitals. In this study, we sought to determine the effectiveness of medical therapeutic communication on the quality of the medical service process in Medan City and obtain statement items that can be used as a questionnaire to assess the same.

\section{Methods}

\section{Study design}

This study received ethical clearance from the Ethics Committee of the Universitas Sumatera Utara (Indonesia) Number 43/KEP/USU/2021. A crosssectional quantitative study was conducted for 4 months (February 01, 2021-May 29, 2021) in three B-class hospitals (Dr. Pirngadi Regional General Hospital, Murni Teguh Memorial Hospital, and Royal Prima Hospital) that have medical services for internal medicine, heart disease, and Ob-Gyn in Medan City.

\section{Respondents}

The study population comprised outpatients visiting the internal medicine, cardiac, and Ob-Gyn polyclinics. In total, 11 internal medicine staff, 8 cardiac staff, and 11 Ob-Gyn staff consented to participate in this study. According to Overeem et al. [23], a minimum of 11 patients are required to assess a medical staff. In this study, accidental sampling was used to select 121 patients from the internal medicine polyclinic, 88 patients from the cardiac polyclinic, and 121 patients from the Ob-Gyn polyclinic. These patients happened to be receiving treatment at the study site at the time of sampling, obtained permission from the responsible medical staff to participate in the study and were willing to follow the course of the study.

\section{Research procedure}

The questionnaire (Table 1), tested for validity and reliability (Table 2), was distributed to patients over 2.5 months. Questionnaires were distributed by direct interviews with patients after their meeting with the medical staff. Each statement in the quality of the medical service process column $(Y)$ was measured using the Guttman scale. For the expectation column, a score of 1 indicated "no expectation" and a score of 0 indicated "expected services." Next, for the reality column, a score of 1 indicated poor treatment experience and 0 indicated good treatment experience.

\section{Data analysis}

Based on the two columns, there were four comparisons between reality and patient expectations: patients do not expect but get good treatment (score 0), patients expect and get good treatment (score 1), patients do not expect and get poor treatment (score 2), and patients expect but received poor treatment (score 3). Each statement in the medical therapeutic communication effectiveness column (X) was measured using the Guttman scale. The statement gets a score of 1 if the patient feels a bad impact and a score of 0 if the patient feels a good impact. All data were in ordinal.

Data were analyzed using partial least squares structural equation modeling (PLS-SEM) with the second-order model two-stage approach (Figure 1) to predict the influence between the constructs and samples. The first test was from the latent construct of the dimension to the indicator. The second was from the latent construct to its dimension construct. The indicator of the latent construct is the dimension construct itself, not the indicator of the dimension construct (not a repeated indicator) [24], [25], [26].

The relationship model between the latent dimension construct in the dependent variable and its indicators were called the outer model for unobserved endogenous variables 1 . This relationship model used a reflective relationship. In Figure 1, it is shown by the arrow from the latent dimensional construct toward the indicators. This happens because each indicator was considered a reflection, embodiment, or impact of the latent construct of its dimensions.

The relationship model between latent variables and latent construct of dimensions in the dependent variable was called the outer model for unobserved endogenous variables 2 . This relationship model uses formative relationships. In Figure 1, it is indicated by the arrow from the latent construct of the dimension to the latent variable. This happens because 


\section{Table 1: Questionnaire guidelines for patients}

\begin{tabular}{lll}
\hline Statement & Do you have any expectation? & How do you feel in reality? \\
& Yes & Bo \\
\hline 1. The doctor is aware of your presence & Bood &
\end{tabular}

2. The doctor stopped their other work

3. The doctor looks friendly (i),(c)

4. The doctor gives greetings (according to the time and

your culture or religion) $)^{(i),(c),(0)}$

5. The doctor introduces themself $(1),(0),(0)$

6. The doctor make eye-contact ${ }^{(0)}$

7. The doctor asks how you are ${ }^{(i),(c),(0)}$

8. The doctor uses understandable words ${ }^{(0)}$

9. The doctor does not seem to be patronizing

10. The doctor welcomes you and your family well ${ }^{(0)}$

11. The doctor treat you as equal to other patients ${ }^{(0)}$

11. The doctor treat you as equal to other patient
12. The doctor asks about your identity ${ }^{(i),(c),(0)}$

13. The doctor asks about your complaints in detail (i),(o)

14. The doctor asks again about the unclear statement ${ }^{(i),(0)}$

15. The doctor can make conversation outside the medical problems $^{(i),(c),(0)}$

16. The doctor can make conversation about private matters ${ }^{(0),(0),(0)}$

17. You feel comfortable expressing your problems $\mathrm{s}^{(i),(0)}$

18. The doctor seems to know what you want ${ }^{(\mathrm{c}),(\mathrm{o})}$

19. The doctor immediately performs the necessary examination and treatment ${ }^{(0)}$

20. The doctor gives you the opportunity to say what's on your mind for $1-2 \min ^{(i)}$

21. The doctor does not interrupt ${ }^{(0)}$

22. The doctor understand the concerns that you do not want to be expressed ${ }^{(\mathrm{c}),(0)}$

23. The doctor understands your feelings ${ }^{(\mathrm{c}),(0)}$

24. The doctor does not judge you ${ }^{(0)}$

25. The doctor does not embarrass you ${ }^{(0)}$

26. The doctor understands the pain you feel ${ }^{(i),(c),(0)}$

27 . You feel much better after talking to the doctor ${ }^{(0)}$

28. You fector ${ }^{(0)}$

examination, and treatment in a soft tone $\mathrm{e}^{(\mathrm{c}),(\mathrm{o})}$

29. The doctor describes your disease, the stages of examination, and treatment in an interesting way ${ }^{(i),(o)}$

30. The doctor describes your disease, the stages of examination, and treatment assertively ${ }^{(0),(0)}$

31. The doctor describes your disease, the stages of examination, and treatment clearly ${ }^{(0)}$

32. The doctor seems to have mastered your disease, the stages of examination, and treatment ${ }^{(0)}$

33. The doctor describes your disease, the stages of examination, and treatment systematically ${ }^{(0)}$

34. The doctor describes your disease, the stages of examination, and treatment openly ${ }^{(0)}$

35. You can explain again about the disease, the stages of examination, and treatment required ${ }^{(0)}$

36. The doctor said they would really do their best in examining and treating ${ }^{(1),(c),(0)}$

37. The doctor seems to really do their best in examining and treating ${ }^{(i),(\infty)}$

38. The doctor said that they really mastered the stages of examination and treatment required ${ }^{(i),(c),(0)}$

39. The doctor seems to know what to do about your problem $^{(0)}$

40. The doctor says that they will help you until you recover $^{(\mathrm{i}),(\mathrm{c}),(\mathrm{o})}$

41. The doctor eliminates your worries about your disease $^{(i),(0)}$

42. The doctor believes that the examination and treatment that you will undergo can successfully treat your disease $^{(0)}$

43. The doctor tries to convince you that the examination and treatment that will be carried out can successfully treat your disease ${ }^{(0)}$

44. The doctor says that you still have to pray, because only with the blessing of God, the doctor can cure your disease ${ }^{(i),(0)}$

45. You believe that with God's blessing, the treatment given by the doctor can cure your disease $e^{(i),(0)}$

46. The doctor asks for your response regarding the way the doctor communicates with the patient ${ }^{(i),(c),(0)}$

47. The doctor asks about your expectation in the examination and treatment as recommended ${ }^{(i),(0),(0)}$

48. You intend to carry out the examination and treatment as recommended by the doctor ${ }^{(0)}$

49. The doctor asks about the reasons for your expectation to carry out examination and treatment ${ }^{(1),(1),(0)}$

50. The doctor apologizes if there is something that is not pleasing to your heart ${ }^{(i),(0)}$

51. The doctor recommends the appropriate doctor if it turns out that they cannot help you to recover ${ }^{(0)}$

52. The doctor can control their emotions when they receive complaints from you ${ }^{(0)}$

53. The doctor promises they will communicate better ${ }^{(i),(0),(0)}$ Information: ${ }^{(1)}:$ Internist, ${ }^{(c)}$ : Cardiologist, ${ }^{\left({ }^{(0)}: \text { Obstetrician. }\right.}$ 
each latent construct of the dimension was considered a partial cause of the latent variable.

The relationship model between the indicators in the independent variable and the latent dimension construct was called the outer model for unobserved exogenous variables 1 . This relationship model used a reflective relationship. In Figure 1 , it is shown by the arrow from the latent dimensional construct toward the indicators. This happens because each indicator was considered a reflection, embodiment, or impact of the latent construct of its dimensions.

Table 2: Questionnaire validity and reliability test

\begin{tabular}{llll}
\hline Validity and reliability & Internist & Cardiologist & Obstetrician \\
\hline Sample for validity and reliability test & 50 & 52 & 43 \\
Standard for corrected item-total correlation & 0.279 & 0.2738 & 0.301 \\
Number of valid and reliable items & 27 & 20 & 48 \\
Cronbach's alpha X & 0.896 & 0.910 & 0.956 \\
Cronbach's alpha Y & 0.923 & 0.873 & 0.961 \\
\hline
\end{tabular}

The model of the relationship between latent variables and the dimension latent construct in the independent variable was called the outer model for unobserved exogenous variables 2 . This relationship model used a reflective relationship. In Figure 1, it is shown by the arrow from the latent variable to the latent dimension construct. This happens because each dimensional latent construct was considered a reflection, embodiment, or impact of the latent variable. The hypothesis of this research was as follows: "There is an impact of medical therapeutic communication effectiveness on the quality of the medical service process in each medical service."

\section{Results}

\section{PLS-SEM analysis}

The PLS-SEM analysis consisted of three steps: Outer model test, inner model test, and hypothesis testing. The outer model test was performed for reflective indicators and formative indicators. The reflective indicators (outer model for unobserved exogenous variables 1 and 2 , also unobserved endogenous variables 1) were tested using convergent validity, discriminant validity, and internal consistency reliability.

The loading factor of the PLS algorithm (Table 3) found two statement items and one latent construct of the impact of medical therapeutic communication in internal medicine polyclinic; three statement items and one latent construct dimension of the impact in cardiology polyclinic; and six statement items and two latent construct dimensions in Ob-Gyn polyclinic (Figure 2a) were $>0.7$. The average variance extracted values also exceeded 0.49 . These results indicate the diversity of indicators possessed by the latent construct

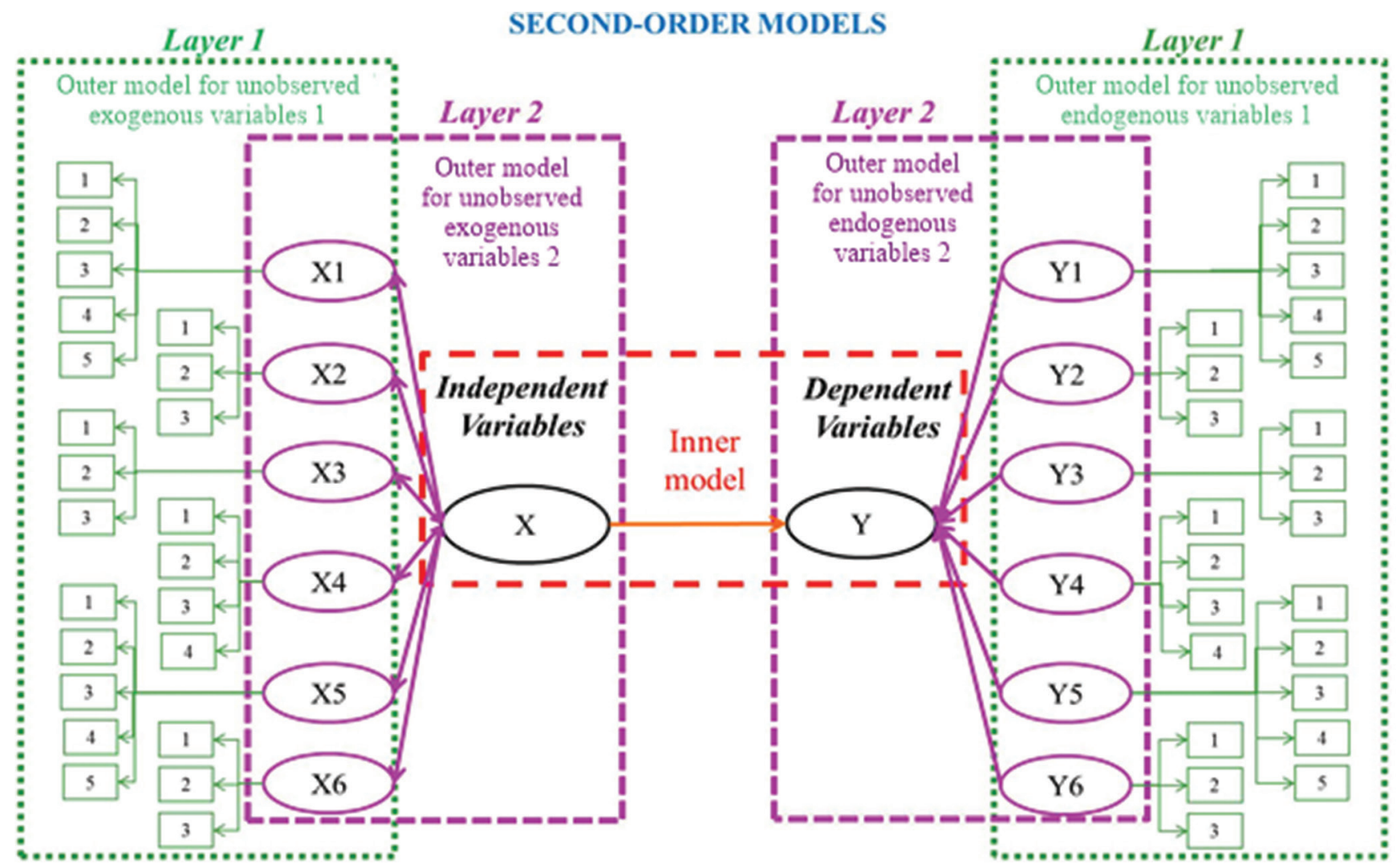

Figure 1: Conceptual framework 
Table 3: Outer model for reflective indicator

\begin{tabular}{|c|c|c|c|c|c|c|c|c|c|c|c|c|}
\hline \multirow{2}{*}{$\begin{array}{l}\text { Outer model } \\
\text { for reflective } \\
\text { indicator }\end{array}$} & \multicolumn{3}{|l|}{ LF } & \multicolumn{3}{|l|}{ AVE } & \multicolumn{3}{|l|}{$\mathrm{CL}$} & \multicolumn{3}{|l|}{ CR } \\
\hline & Inter nist & Cardio logist & Obstetrician & Internist & Cardio logist & Obstetri cian & Internist & Cardio logist & Obstetrician & Internist & Cardio logist & Obstetri cian \\
\hline \multicolumn{13}{|l|}{$\mathrm{X}$} \\
\hline X3 & & & 0.895 & & & 0.775 & & & 0.895 & & & 0.874 \\
\hline X3.2.2 & & & 0.914 & & & 0.754 & & & 0.914 & & & 0.902 \\
\hline X3.3.1 & & & 0.817 & & & 0.754 & & & 0.817 & & & 0.902 \\
\hline X3.3.2 & & & 0.871 & & & 0.754 & & & 0.871 & & & 0.902 \\
\hline X4 & & & 0.866 & & & 0.775 & & & 0.866 & & & 0.874 \\
\hline X4.1.1 & & & 0.878 & & & 0.674 & & & 0.878 & & & 0.861 \\
\hline X4.1.2 & & & 0.731 & & & 0.674 & & & 0.731 & & & 0.861 \\
\hline X4.4.2 & & & 0.847 & & & 0.674 & & & 0.847 & & & 0.861 \\
\hline X5 & 1.000 & 1.000 & & 1.000 & 1.000 & & 1.000 & 1.000 & & 1.000 & 1.000 & \\
\hline X5.1.1 & 0.538 & 0.958 & & 0.900 & 0.929 & & 0.538 & 0.958 & & 0.947 & 0.975 & \\
\hline$\times 5.2 .1$ & 0.516 & 0.975 & & 0.900 & 0.929 & & 0.516 & 0.975 & & 0.947 & 0.975 & \\
\hline X5.3.1 & & 0.958 & & & 0.929 & & & 0.958 & & & 0.975 & \\
\hline \multicolumn{13}{|l|}{ Y } \\
\hline Y3.2.2 & & & 0.932 & & & 0.795 & & & 0.932 & & & 0.921 \\
\hline Y3.3.1 & & & 0.870 & & & 0.795 & & & 0.870 & & & 0.921 \\
\hline Y3.3.2 & & & 0.871 & & & 0.795 & & & 0.871 & & & 0.921 \\
\hline Y4.1.1 & & & 0.879 & & & 0.684 & & & 0.879 & & & 0.866 \\
\hline Y4.1.2 & & & 0.785 & & & 0.684 & & & 0.785 & & & 0.866 \\
\hline Y4.4.2 & & & 0.815 & & & 0.684 & & & 0.815 & & & 0.866 \\
\hline Y5.1.1 & 0.534 & 0.884 & & 0.876 & 0.831 & & 0.534 & 0.884 & & 0.934 & 0.936 & \\
\hline Y5.2.1 & 0.534 & 0.937 & & 0.876 & 0.831 & & 0.534 & 0.937 & & 0.934 & 0.936 & \\
\hline Y5.3.1 & & 0.913 & & & 0.831 & & & 0.913 & & & 0.936 & \\
\hline
\end{tabular}

of the impact of medical therapeutic communication, latent construct of the patient satisfaction dimension, and latent variable of the medical therapeutic communication effectiveness (convergent validity).

The cross loading values that were $>0.7$ indicate that the reflective indicator has a strong relationship with the latent construct of its dimension compared with other indicators (discriminant validity). The composite reliability also $>0.7$ demonstrate the high internal consistency of the measurement used. The outer model test for formative indicators (unobserved endogenous variables 2) was analyzed using significance of weights and multicollinearity. The significance value of outer weight for medical staff in internal medicine and cardiology was $<1.96$ (Table 4), and the results of Bootstrapping $p$ value is not shown. These results indicate that the value of the formative indicator weight with the construct was not significant. Therefore, the measurement was not feasible (invalid and reliable), and it cannot be continued to the inner model analysis.

The Ob-Gyn staff has an outer weight of $>1.96$, a $p<0.05$, and the VIF values of $>5$, indicating a significant construct and absence of multicollinearity between indicators. Therefore, the measurement used was feasible, and it can be used to analyze the inner model. The inner model analysis comprised determination of reflective and formative indicators. The reflective indicators were tested using the coefficient of determination $\left(R^{2}\right)$, predictive relevance $\left(Q^{2}\right)$, and goodness of fit (GoF) values from the latent construct dimension of the medical therapeutic communication impact.

The Bootstrapping using 200 samples (Figure $2 \mathrm{~b}$ ) resulted in an $\mathrm{R}^{2}$ of $>0.75$ (Table 5 ). This value indicates a strong relationship between patients' feeling that their complaints are heard (X3) and that they understand the stages of examination and treatment (X4) with the medical therapeutic communication effectiveness $(X)$ in the Ob-Gyn polyclinic.
Based on the construct cross-validated redundancy from blindfolding results (Figure $2 \mathrm{c}$ ), the value of $Q^{2}$ (Table 5 ) was $>0$. This shows that the values observed in the two latent construct dimensions of the medical therapeutic communication impact have been well reconstructed. Therefore, it can be concluded that the inner model for reflective indicators has predictive relevance for the relative influence of the structural model on the measurement of observation for latent variables of the medical therapeutic communication effectiveness in the Ob-Gyn polyclinic. The GoF value of $>0.36$ shows that the observation data strongly support the PLS-SEM model.

The inner model analysis for formative indicators was only based on the $R^{2}$ and $Q^{2}$. The latent variable of the quality of medical service process $(\mathrm{Y})$ demonstrated an $R^{2}$ value of $>0.75$ (Table 5), which indicates a strong relationship between the medical therapeutic communication effectiveness $(X)$ and the quality of medical service process $(Y)$. It also indicates that the two latent construct dimensions of patient satisfaction ( $Y 3$ and $Y 4$ ) have a strong relationship with the quality of medical service process $(Y)$ in the Ob-Gyn polyclinic.

Based on the construct cross-validated redundancy from blindfolding results (Figure $2 \mathrm{c}$ ), the quality of medical service process $(Y)$ in the Ob-Gyn polyclinic had a $Q^{2}$ value of $>0$, which indicates that the observed values in this variable have been reconstructed properly. Therefore, the inner model for formative indicators has predictive relevance for the relative influence of the structural model on the measurement of observations.

The statistical analysis proved that the structural model built in this study was robust and accurate. Thus, it can be used for testing the hypothesis. The hypothesis was tested using the probability values of the medical therapeutic communication effectiveness $(X)$ with the quality of medical service process $(Y)$ variables. Based on the path coefficients (Figure $2 b$ ), 


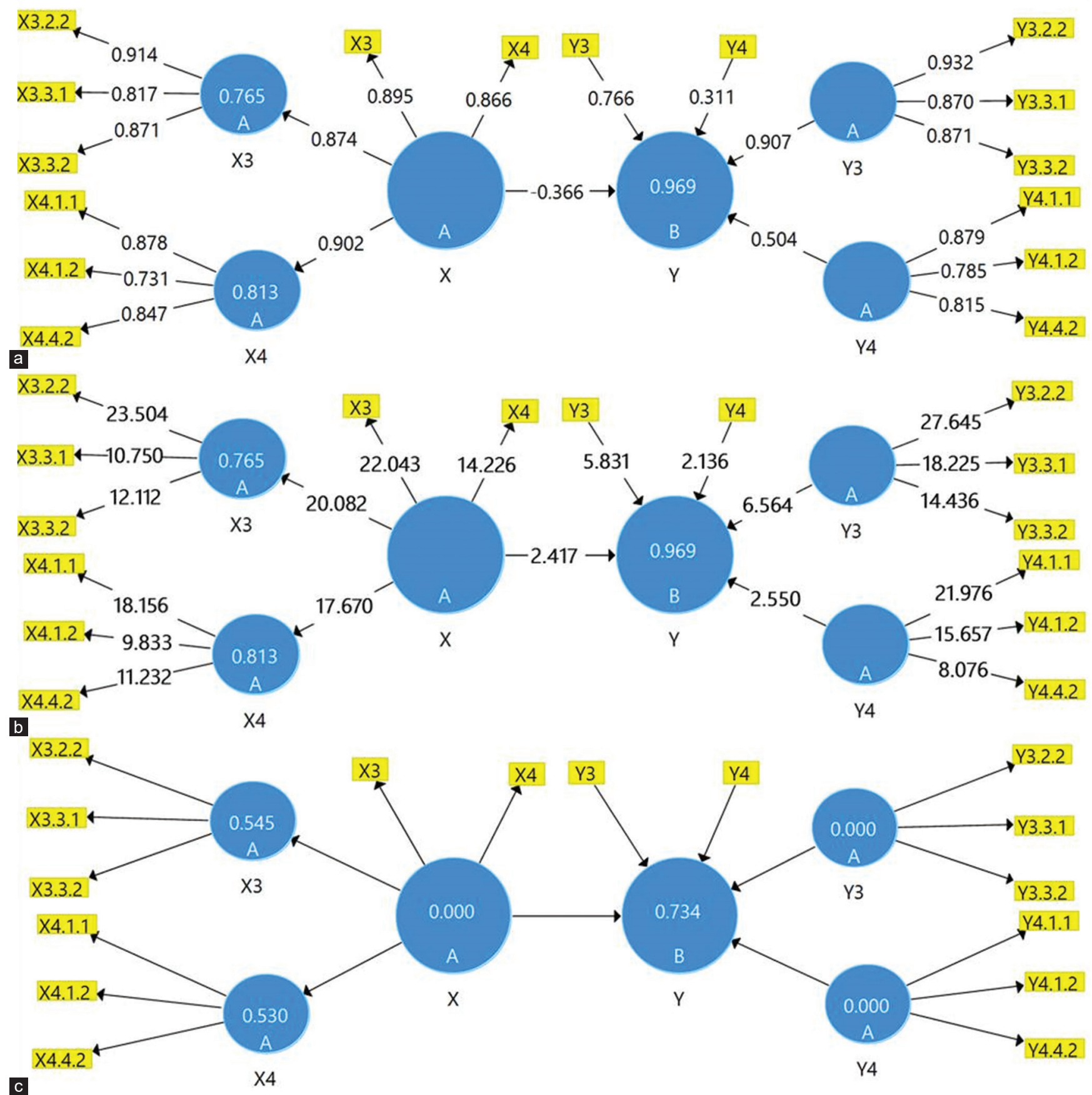

Figure 2: (a-c) Partial least squares structural equation modeling Analysis of obstetrics-gynecology Medical staff

the probability were 2.417 and $p$ values were 0.017 Thus, $\mathrm{HO}$ was rejected, and $\mathrm{Ha}$ was accepted. Therefore, it can be concluded that there is an impact of medical therapeutic communication effectiveness on the quality of the medical service process in the Ob-Gyn polyclinic.

\section{Frequency distribution after PLS-SEM}

\section{analysis}

The communication by the medical staff in the Ob-Gyn polyclinic was found to be effective and had an impact on the quality of the medical service process (Table 6). This effectiveness was indicated by

Table 4: Outer model for formative indicators

\begin{tabular}{|c|c|c|c|c|c|c|c|c|c|}
\hline \multirow{3}{*}{$\begin{array}{l}\text { Outer model } \\
\text { for formative } \\
\text { indicators }\end{array}$} & \multicolumn{6}{|c|}{ Statistical weight } & \multicolumn{3}{|c|}{ Multicollinearity } \\
\hline & \multicolumn{3}{|c|}{ Significance of outer weights } & \multicolumn{3}{|l|}{ p-values } & \multicolumn{3}{|l|}{ VIF } \\
\hline & Internist & Cardiologist & Obstetrician & Internist & Cardiologist & Obstetrician & Internist & Cardiologist & Obstetrician \\
\hline Y3 & & & 5.831 & & & 0.000 & & & 1.789 \\
\hline Y4 & & & 2.136 & & & 0.034 & & & 1.789 \\
\hline Y5 & 0.0001 & 0.0001 & & & & & 1.000 & 1.000 & \\
\hline
\end{tabular}


Table 5: Inner model for reflective and formative indicators

\begin{tabular}{lllllll}
\hline Inner model & $\mathrm{R}^{2}$ & $\mathrm{Q}^{2}$ & $\mathrm{AVE}$ & VAVE & Average $\mathrm{R}^{2}$ & $\mathrm{GoF}$ \\
\hline Reflective indicator & & & & & & \\
$\quad$ X3 & 0.765 & 0.545 & 0.754 & 0.87 & 0.79 & 0.685 \\
$\quad$ X4 & 0.813 & 0.530 & 0.674 & 0.82 & & 0.648 \\
$\begin{array}{l}\text { Formative Indicator } \\
\quad \mathrm{Y}\end{array}$ & 0.969 & 0.734 & & & & \\
\multicolumn{2}{l}{ AVE: Average variance extracted, GoF: Goodness of fit. } & & & &
\end{tabular}

patients who felt their complaints were heard and they well understood the disease, stages of examination, and treatment. The quality of the medical service process was visible from patient satisfaction when the medical staff listened to patients and explained them the disease, stages of examination, and treatment in detail.

The items that patients expected from the medical staff are listed in Table 6. The items included the following: medical staff must have empathy for patients, understand their suffering (sympathy), make them feel relieved, and describe the disease, stages of examination, and treatment in a soft tone, interesting manner until they understand.

Table 6: Frequency distribution after PLS-SEM analysis

\begin{tabular}{|c|c|c|}
\hline Frequency distribution & $\mathrm{n}$ & $\%$ \\
\hline \multicolumn{3}{|l|}{ Latent variable Y } \\
\hline Quality service & 115 & 95.0 \\
\hline Poor service & 6 & 5.0 \\
\hline \multicolumn{3}{|l|}{ Latent variable $\mathrm{X}$} \\
\hline Effective communication & 115 & 95.0 \\
\hline Ineffective communication & 6 & 5.0 \\
\hline \multicolumn{3}{|l|}{ Latent construct of patient satisfaction dimension $\mathrm{Y} 3$} \\
\hline Satisfied & 110 & 90.9 \\
\hline Not satisfied & 6 & 5.0 \\
\hline Very dissatisfied & 5 & 4.1 \\
\hline \multicolumn{3}{|l|}{ Latent construct of patient satisfaction dimension Y4 } \\
\hline Very satisfied & 2 & 1.7 \\
\hline Satisfied & 98 & 81.0 \\
\hline Not satisfied & 17 & 14.0 \\
\hline Very dissatisfied & 4 & 3.3 \\
\hline \multicolumn{3}{|c|}{ Latent construct of medical therapeutic communication impact dimension } \\
\hline \multicolumn{3}{|c|}{ X3 } \\
\hline Suitable for communication purposes & 115 & 95.0 \\
\hline Not suitable for communication purposes & 6 & 5.0 \\
\hline \multicolumn{3}{|c|}{ Latent construct of medical therapeutic communication impact dimension } \\
\hline \multicolumn{3}{|l|}{ X4 } \\
\hline Suitable for communication purposes & 113 & 93.4 \\
\hline Not suitable for communication purposes & 8 & 6.6 \\
\hline \multicolumn{3}{|l|}{ Statement item } \\
\hline \multicolumn{3}{|l|}{ The doctor understands your feelings } \\
\hline The patient expected and gets good treatment & 114 & 94.2 \\
\hline The patient did not expect and gets bad treatment & 1 & 0.8 \\
\hline The patient expected but gets bad treatment & 6 & 5.0 \\
\hline \multicolumn{3}{|l|}{ The doctors understand your suffering } \\
\hline The patient did not expect but gets good treatment & 1 & 0.8 \\
\hline The patient expected and gets good treatment & 109 & 90.1 \\
\hline The patient did not expect and gets bad treatment & 2 & 1.7 \\
\hline The patient expected but gets bad treatment & 9 & 7.4 \\
\hline \multicolumn{3}{|l|}{ You feel much better after talking to the doctor } \\
\hline The patient expected and gets good treatment & 114 & 94.2 \\
\hline The patient expected but gets bad treatment & 7 & 5.8 \\
\hline \multicolumn{3}{|c|}{$\begin{array}{l}\text { The doctor describes your disease, the stages of examination, and } \\
\text { treatment in a soft tone }\end{array}$} \\
\hline The patient did not expect but gets good treatment & 2 & 1.7 \\
\hline The patient expected and gets good treatment & 113 & 93.4 \\
\hline The patient expected but gets bad treatment & 6 & 5.0 \\
\hline \multicolumn{3}{|c|}{$\begin{array}{l}\text { The doctor describes your disease, the stages of examination, and } \\
\text { treatment openly }\end{array}$} \\
\hline The patient did not expect but gets good treatment & 4 & 3.3 \\
\hline The patient expected and gets good treatment & 96 & 79.3 \\
\hline The patient did not expect and gets bad treatment & 2 & 1.7 \\
\hline The patient expected but gets bad treatment & 19 & 15.7 \\
\hline \multicolumn{3}{|c|}{$\begin{array}{l}\text { You can re-explain the disease, the stages of examination, and treatment } \\
\text { required }\end{array}$} \\
\hline The patient expected and gets good treatment & 114 & 94.2 \\
\hline The patient did not expect and gets bad treatment & 1 & 0.8 \\
\hline The patient expected but gets bad treatment & 6 & 5.0 \\
\hline
\end{tabular}

\section{Discussion}

In this study, we observed that the medical staff at the Ob-Gyn polyclinic properly listened and explained the treatment course to their patients. This observation is in line with the study by Rahmania and Saragih [27], who found that therapeutic communication techniques applied by Ob-Gyn physicians involved showing acceptance, listening, clarifying, focusing, conveying observations, silence, summarizing, giving gifts, allowing clients to start a conversation, suggesting to continue the conversation, and encouraging clients to describe their perceptions. However, their research was a qualitative study, in contrast to our research, which was quantitative.

The outer model for reflective and formative indicators in the Ob-Gyn polyclinic was feasible because it had large convergent validity, strong discriminant validity, and high internal consistency. The two latent constructs of patient satisfaction dimensions were also significantly related to the variable of the quality of medical service, and each latent construct did not have multicollinearity between one another. The results of this study are similar to those in The Generic Short Patient Experiences Questionnaire (GS-PEQ) from Sjetne et al. [28]. They mentioned five items related to medical staff that have been tested for validity and reliability and are used as the core of the GS-PEQ in Norway. One of them is that the medical staff explains in a manner that is easily understood by patients. However, the statement item in this study was more detailed about the method used by the medical staff. It stated that the medical staff must explain in a soft tone and interesting manner such that patients can re-state the details of their disease, examination, and treatment.

This study also supports the Multisource Feedback from Overeem et al. [23]. This study revealed 17 items that had been tested and were used to assess the professional performance of medical staff in the Netherlands. The items related to medical staff were explaining the disease, treatment options and plans, physical examinations, and other things that may occur at unexpected times. Moreover, Pompili et al. [29] described 11 items that had been tested and were used to assess patients' self-confidence in choosing treatment for earlystage lung cancer in the United Kingdom, including patients' understanding of the disease, treatment options, and the benefits and risks of each treatment option. However, both researches have no statement items regarding medical staff listening to patients or patients feeling their complaints were heard by the medical staff.

This study found that patients' perception of being heard and understanding the explanation provided by the medical staff strongly correlated with the medical therapeutic communication effectiveness. This observation is in line with the opinions of 
experts [19], [17] dan and the results of several previous studies [30], [31], [32], [33], [34]. Medical staff that shows empathy and sympathy when actively listening to patient complaints can increase patient satisfaction, and thus, the overall quality of medical services. The opinion of Herqutanto [35] and research by Langewitz et al. [36] also support this aspect. They state that medical staff must actively listen to patient complaints without interrupting until they finish in about 1-2 min. After listening to the patient's explanation, the medical staff performs a physical examination (weight and blood pressure), ultrasonography, and other necessary investigations before making a diagnosis. The medical staff then explains the results to patients until they understand the diagnosis made.

Based on the opinions ofexperts [15], [16], [17], [18], [19] and the results of previous studies [34], [37], medical staff must explain gently (tenderness), be assertive, authoritative, open about their condition, stages of examination, and treatment (forthright). This explanation needs to be adjusted to the culture, knowledge, and education of the patient. The medical staff indulgently explains to the patient until the patient fully understands the diagnosis. Bendapudi [30], Herqutanto [35], and others [33], [38], [39] also state that frank and complete explanation of the diagnosis by the medical staff is an ideal behavior. Medical staff that ensures all patient questions are answered increases patient satisfaction and avoids medical lawsuits. Wirakesuma et al. [40] stated that one of the factors that may lead to medical lawsuits is unclear communication by medical staff.

\section{Conclusions}

Based on the PLS-SEM analysis of each medical service, we found that the medical therapeutic communication effectiveness affected the quality of the medical service process only in the Ob-Gyn polyclinic. This effectiveness was experienced by patients who felt their complaints were heard and they understood the disease, stages of examination, and treatments properly. The quality of the medical service process was observed from patient satisfaction when the medical staff actively listened to their complaints and explained to them the disease, stages of examination, and treatments properly. These results indicate that the medical staff in Ob-Gyn polyclinics should focus more on listening to the patient's complaints with a sense of empathy and sympathy, so that they feel relieved. The medical staff must also be forthright about the patient's condition and explain it in an interesting way and a soft tone such that the patient can re-iterate.

\section{Authors' Contribution}

AML- Contributed to the concept and design of the study, statistical analyses, interpretation of the data, drafting of the manuscript, and gave final approval for submission of the manuscript. HN- Contributed to statistical analyses, interpretation of the data, drafting of the manuscript, and gave final approval for submission of the manuscript. ZZ- Contributed to statistical analyses, interpretation of the data, drafting of the manuscript, and gave final approval for submission of the manuscript. JJ- Contributed to statistical analyses, interpretation of the data, drafting of the manuscript, and gave final approval for submission of the manuscript.

\section{Availability of Data and Materials}

The datasets used and/or analyzed during the current study are available from the corresponding author on reasonable request.

\section{Ethics Approval and Consent to Participate}

This research has received ethical clearance from the Ethics Committee of the Universitas Sumatera Utara (Indonesia) Number 43/KEP/USU/2021.

\section{Patient Consent for Publication}

In the consent form for the patient's participation in the study, it is written that the patient allows the publication of information from the results of this study anonymously.

\section{Informed Consent}

Written informed consent was obtained from a legally authorized representative(s) (the Ethics Committee of the Universitas Sumatera Utara [Indonesia]) for anonymized patient information to be published in this article. 


\section{Significance for Public Health}

Health services provided by the medical staff are called medical services. Quality medical services can improve the health status of the community. Quality medical services require effective medical therapeutic communication. Medical therapeutic communication is said to be effective when the patient recovers from the disease.

\section{References}

1. Smallwood P. Using the JCAHO's Six Competencies to Evaluate MD Performance. Vol. 2. Hospitalist Management Advisor; 2006. p. 1-12.

2. Herlambang S. Manajemen Pelayanan Kesehatan Rumah Sakit: Cara Mudah Memahami Manajemen Pelayanan di Rumah Sakit dan Organisasi Pelayanan Kesehatan Lainnya [Hospital Health Service Management: An Easy way to Understand Service Management in Hospitals and other Health Care Organizations]. $1^{\text {st }}$ ed. Yogyakarta: Gosyen Publishing; 2016.

3. Sangadji EM, Sopiah. Perilaku Konsumen: Pendekatan Praktis [Consumer Behavior: A Practical Approach]. $1^{\text {st }}$ ed. Yogyakarta: Andi Offset; 2013.

4. Sarassati I. Faktor-Faktor Yang Mempengaruhi Masyarakat Memilih Pengobatan Medis Ke Luar Negeri (Study Terhadap Masyarakat Kota Medan yang Berobat Ke Penang, Malaysia) [Factors Influencing People to Choose Medical Treatment Abroad (Study of Medan City Communities Who Go to Penang, Malaysia)] [Skripsi]. Medan: Universitas Sumatera Utara; 2008.

5. Ombi IP. Kepercayaan Pasien terhadap Dokter Lokal dan Dokter di Luar Negeri: Studi Komparasi pada Pasien yang Berobat ke Luar Negeri [Patient's Trust in Local Doctors and Doctors Abroad: A Comparative Study on Patients Treating Abroad] [Skripsi]. Medan: Universitas Sumatera Utara; 2012.

6. Panggabean P. Pengaruh Persepsi Tentang Kualitas Pelayanan Kesehatan Terhadap Kepuasan dan Intensitas Warga Kota Medan Berobat Keluar Negeri [The Influence of Perceptions About the Quality of Health Services on the Satisfaction and Intensity of Medan City Residents for Treatment Abroad] [Tesis]. Medan: Universitas Sumatera Utara; 2015.

7. Salim SR, Sutarman Y. Perilaku Warga Indonesia Dalam Menggunakan Jasa Medis di Dalam dan di Luar Negeri [The Behavior of Indonesian Citizens in Using Medical Services at Home and Abroad]; 2016.

8. Bali P. 550,000 Indonesians Go To Malaysia for Medical Treatment per Year. AntaraNews; 2015.

9. Rusman A, Fiona J. NTP Boosts Medical Tourism. Kuala Lumpur: New Straits Times Press; 2018 Available from: https:// www.nst.com.my/news/nation/2018/04/362247/ntp-boostsmedical-tourism [Last accessed on 2018 Apr 27].

10. Vashu D, Masri R, Cham TH, editors. The Role of Destination Image in Malaysia's Medical Tourism Industry. International Conference on Social and Behavioral Sciences October. Singapore: American Scientific Publishers; 2017.

11. Konsulat Jenderal Republik Indonesia Penang. Laporan Kinerja (LKj) Konsulat Jenderal Republik Indonesia Penang tahun 2015 [Performance Report (LKj) of the Consulate General of the Republic of Indonesia Penang in 2015]. Penang: Konsulat Jenderal Republik Indonesia-Penang; 2016.
12. Au Yong HN. Positioning Malaysia in medical tourism: Implication on economic growth in ASEAN integration. Indones J Bus Econ 2018;1:49-73.

13. Kumar J, Hussain K. Factors affecting medical tourism destination selection: A Malaysian perspective. Int Interdiscip Bus Econ Adv J. 2016;1(1):1-10.

14. Jannah KD. Analisis Kualitas Pelayanan Kesehatan untuk Mewujudkan Kepuasan Pasien pada Rumah Sakit "Siti Khodijah" Pekalongan [Analysis of Health Service Quality to Achieve Patient Satisfaction at the "Siti Khodijah" Hospital Pekalongan] [Tesis]. Semarang: Universitas Diponegoro; 2001.

15. Mardjikoen B, Fadhilah M, Auda R, Akbar FN. Komunikas Efektif Dokter-pasien [Effective Doctor-Patient Communication]. $1^{\text {st }}$ ed. Jakarta: UIN Jakarta Press; 2015.

16. Ganiem LM. Komunikasi Kedokteran: Konteks Teoritis dan [Medical Communication: Theoretical and Practical Context]. $1^{\text {th }}$ ed. Depok: Prenadamedia Group; 2018.

17. Lalongkoe MR, Edison TA. Komunikasi Terapeutik: Pendekatan Praktis Praktisi Kesehatan [Therapeutic Communication: A Health Practitioner's Approach]. $1^{\text {st }}$ ed. Yogyakarta: Graha IImu; 2014.

18. Sunarto. Suyono YJ, editor. Diagnosis Klinis Awal: Dari Masalah Menuju Diagnosis [Early Clinical Diagnosis: From Problem to Diagnosis]. $2^{\text {nd }}$ ed. Jakarta: EGC; 2013.

19. Konsil Kedokteran Indonesia. Manual Komunikasi Efektif Dokter Pasien [Doctor Patient Effective Communication Manual]. $1^{\text {st }}$ ed. Jakarta: Konsil Kedokteran Indonesia; 2009.

20. Sari DP. Pengaruh Komunikasi Terapeutik Dokter Terhadap Kepuasan Ibu Bersalin di Rumah Sakit Jitra Bhayangkara Bengkulu [The Effect of Doctor's Therapeutic Communication on Maternal Satisfaction at Jitra Bhayangkara Hospital Bengkulu] [Skripsi]. Bengkulu: Universitas Bengkulu; 2013.

21. Kourakos M, Fradelos EC, Papathanasiou IV, Saridi M, Kafkia T. Communication as the basis of care for patients with chronic diseases. Am J Nurs 2017;7:7-12

22. Martin KL. Refocusing physician-patient communication. Med Econ 2017;94:14-5,8-9.

23. Overeem K, Wollersheim HC, Arah OA, Cruijsberg JK, Grol RP, Lombarts KM. Evaluation of physicians' professional performance: An iterative development and validation study of multisource feedback instruments. BMC Health Serv Res 2012;12:80. http://doi.org/10.1186/1472-6963-12-80 PMid:22448816

24. Hair JF Jr., Hult GT, Ringle CM, Sarstedt M. A Primer on Partial Least Squares Structural Equation Modeling (PLS-SEM). 2nd. Kennesaw State University, USA : SAGE Publications, Inc.; 2017. [Accessed: June 12, 2021] Available from : https:// pdfcoffee.com/download/a-primer-on-partial-least-squaresstructural-equation-modeling-2017-pdf-free.html

25. Hair Jr., J.F., et al., When to use and how to report the results of PLS-SEM. European Business Review, 2018. 31(1): p. 2-24.

26. Hair JF Jr., Black WC, Babin BJ, Anderson RE. Multivariate Data Analysis. $8^{\text {th }}$ ed. United Kingdom: Annabel Ainscow; 2019.

27. Rahmania AA, Saragih R. Penerapan komunikasi terapeutik dalam pelayanan kesehatan (studi komunikasi terapeutik dokter spesialis obstetri dan ginekologi dengan pasien ibu hamil pada praktik dokter bersama di apotel Al-Khair Bengkulu) [Application of therapeutic communication in health services (study of therapeutic communication of obstetrics and gynecology specialists with pregnant women patients at joint doctor's practice at Al-Khair Apotel Bengkulu)]. J Kaganga. 2019;3(1):13-21.

28. Sjetne IS, Bjertnaes OA, Olsen RV, Iversen HH, Bukholm G The generic short patient experiences questionnaire (GS-PEQ): Identification of core items from a survey in Norway. BMC Health Serv Res. 2011;11(1):88. 
29. Pompili C, Holch P, Rogers Z, Absolom K, Clayton B, Franks K, et al. Patients' confidence in treatment decisions for early stage non-small cell lung cancer (NSCLC). Health Qual Life Outcomes. 2020;18(1):237.

30. Bendapudi NM, Berry LL, Frey KA, Parish JT, Rayburn WL, editors. Patients' Perspectives on Ideal Physician Behaviors. Amsterdam, Netherlands: Mayo Clinic Proceedings, Elsevier; 2006.

31. Prasanti D. Komunikasi terapeutik tenaga medis dalam pemberian informasi tentang obat tradisional bagi masyarakat [Therapeutic communication of medical workers in providing information on traditional medicines for the community]. MediaTor (J Komunikasi). 2017;10(1):53-64.

32. Halim S, Nasution SL, Ginting CN, Girsang E, editors. Identification of Service Quality Factors and Patient Satisfaction Level toward Specialist Doctor Treatment. The International Conference on Health Informatics, Medical, Biological Engineering, and Pharmaceutical (HIMBEP 2020); $202023^{\text {th }}-25^{\text {th }}$ September, 2020; Medan (Virtual through Zoom Meeting): SCITEPRESS Science and Technology Publications, Lda. All Rights Reserved.

33. Berlian, E.R., E.S. Redjeki, and D. Mawarni, Patient Perspectives on Quality of Health Services in Mulyorejo Public Health Centre. KnE Life Sciences, 2021. 6(2): p. 412-425.

34. Osuna E, Pérez-Carrión A, Pérez-Cárceles MD, Machado F. Perceptions of health professionals about the quality of communication and deliberation with the patient and its impact on the health decision making process. J Public Health Res. 2018;7(3):1445. http://doi.org/10.4081/jphr.2018.1445 PMid:30687676

35. Herqutanto. Wahai dokter Indonesia, berkomunikasilah [O Indonesian doctor, communicate]. Majalah Kedokteran Indonesia. 2009;59(2):35-8.

36. Langewitz W, Denz M, Keller A, Kiss A, Rüttimann S, Wössmer B. Spontaneous talking time at start of consultation in outpatient clinic: Cohort study. BMJ. 2002;325(7366):682-3. http://doi.org/10.1136/bmj.325.7366.682 PMid: 12351359

37. Situmeang IV, Situmeang IR. Komunikasi dokter yang berpusat pada pasien di masa pandemi [Patient-centered physician communication during a pandemic]. MEDIALOG. 2021;4(1):130-41.

38. Chastain AM. Patient and Provider Perspectives on Sexual History Taking During Gynecological Care: A Pilot Study in an Academic Family Medical Setting in New York City [Dissertation]. Ann Arbor: City University of New York; 2019.

39. Novita D, Yenni RA, Syafruddin S. Pelaksanaan kolaborasi komunikasi antara dokter-pasien di rumah sakit kota Padang [Implementation of collaborative communication between doctor-patients at Padang city hospital]. TRIK. 2021;11(1):42-5.

40. Wirakesuma MT, Junaidi $P$, Syarli $S$. Analisis kasus gugatan medis di rumah sakit harapan bunda batam [Analysis of medical accusation in harapan bunda batam hospital]. Medihealth. 2020;1(1):21-33. 